\title{
Congenital erosive and vesicular dermatosis: an atypical presentation of a rare dermatosis
}

\author{
Ana Gusmão Palmeiro, ${ }^{1}$ Leandro Silva, ${ }^{1}$ Ana Lança (i) $^{2}$ Cristina Amaro ${ }^{1}$
}

\begin{abstract}
${ }^{1}$ Dermatology, Centro Hospitalar de Lisboa Ocidental EPE Hospital de Egas Moniz, Lisbon, Portugal

${ }^{2}$ Pediatrics, Centro Hospitalar de Lisboa Ocidental EPE Hospital de São Francisco Xavier, Lisbon, Portugal
\end{abstract}

\section{Correspondence to}

Dr Ana Gusmão Palmeiro: apgpalmeiro@gmail.com

Accepted 9 February 2022

\section{DESCRIPTION}

Congenital erosive and vesicular dermatosis (CEVD) is a rare condition of unknown origin. Classically, it presents at birth with erythema, vesicles, erosions, crusts and fissures, involving over $75 \%$ of the skin. ${ }^{1}$ The lesions heal spontaneously within 10 days -3 months, leaving behind a pathognomonic reticulate scarring. ${ }^{1-3}$

The authors present the case of a boy, born prematurely at 25 weeks' gestation by an emergency caesarean delivery to a 31-year-old woman (gravida 1, para 0). The pregnancy had been uneventful, with adequate follow-up. The newborn was admitted to the neonatal intensive care unit for severe respiratory distress syndrome (hyaline membrane disease). Although he did not present with any skin changes at birth, after a few weeks, a small erythematous plaque, with hypopigmentated

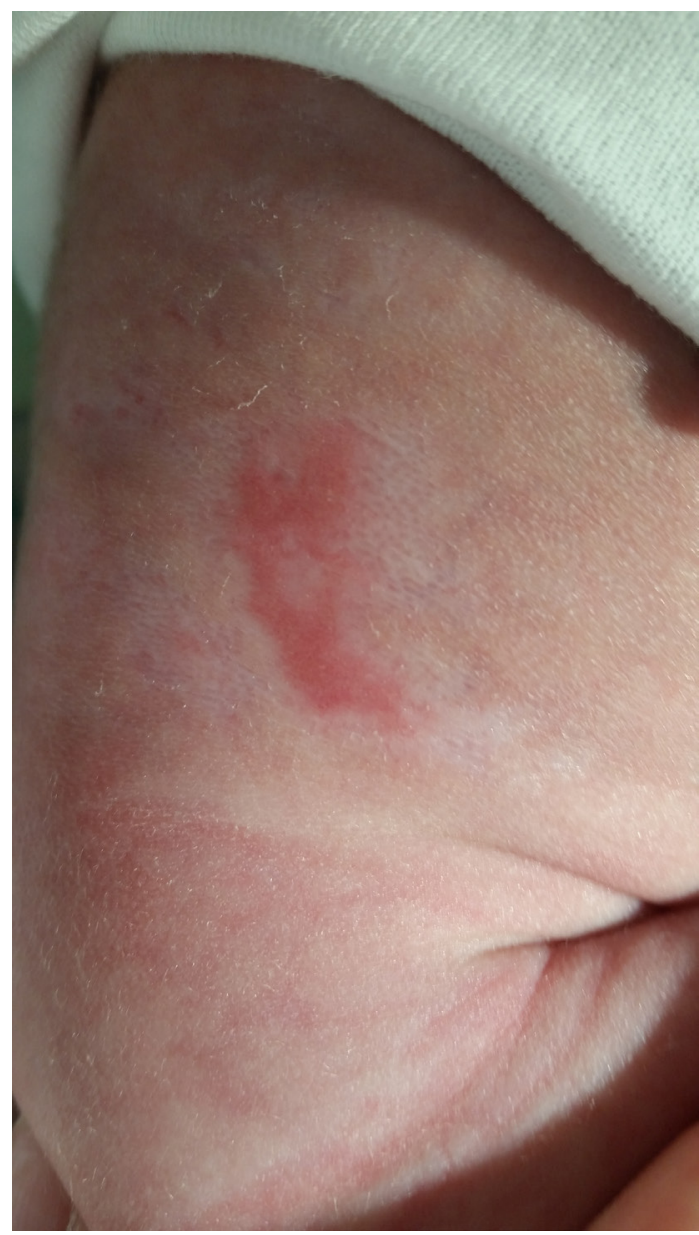

Figure 1 Small erythematous plaque, first observed in the neonatal intensive care unit.

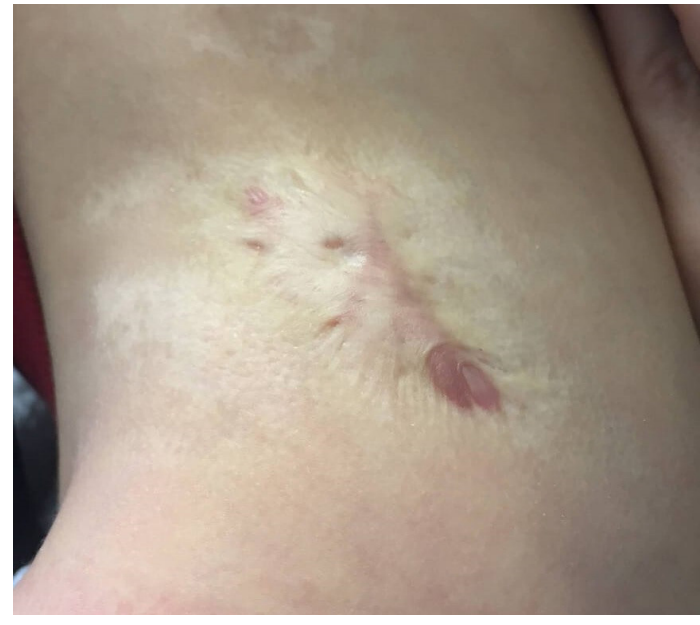

Figure 2 Scar tissue at 3 years old, note the peculiar shape and cribriform surface.

regions and a cribriform surface, was noted on his left flank (figure 1). There was no apparent traumatic cause and serological tests of syphilis, hepatitis, toxoplasmosis, rubeola, cytomegalovirus and herpes simplex virus (HSV) 1 and HSV2 revealed negative. The infant had favourable evolution and was discharged from the unit after 94 days.

He presented to the dermatology outpatient clinic 10 months after his birth. On his left flank, he had a $3 \mathrm{~cm}$ cicatricial-like cribriform plaque, with elevated pink tissue surrounded by a whitish perilesional halo, as well as a smaller identical lesion on the periumbilical region. A punch biopsy of the larger lesion revealed scar tissue and small foci of granulomatous foreign body reaction.

Considering the exclusion of possible differential diagnosis, the course of the dermatosis, the histopathology and the typical scaring, a diagnosis of CEVD was made.

There are less than 40 cases of CEVD reported. Aetiological hypotheses include intrauterine infections, amniotic adhesions, birth trauma and a developmental defect with unusual healing in premature skin. ${ }^{145}$ It is strongly associated with prematurity, although a few cases have been reported in full-term infants. $^{2} 3$ Other associations include nail abnormalities, hyperthermia/hypohidrosis, maternal chorioamnionitis, alopecia, neurodevelopmental and ophthalmological abnormalities, and tongue atrophy. These patients may also be prone to postnatal herpetic superinfections. ${ }^{1}$

Differential diagnosis comprehends amniotic construction bands, congenital infections, epidermolysis bullosa, incontinentia pigmenti, focal 
dermal hypoplasia, aplasia cutis congenita and autoimmune bullous diseases. The exclusion of these differentials and the development of the characteristic supple-reticulated scarring establish the diagnosis. ${ }^{1}$

The histopathological findings depend on the stage of the disease. In early inflammatory lesions, there are reports of epidermal necrosis, subepidermal vesiculation and an eroded epidermis with a predominantly neutrophilic or mixed dermal infiltrate, while late lesions show scar tissue. ${ }^{1}$

Our patient presented with atypical clinical features, such as the development of the lesions after birth (which, to the authors' knowledge, was reported only in two other cases) and the limited extent of skin involvement. ${ }^{23}$ At the current time, he is 3 years old (figure 2) and keeping regular massages of the cicatricial tissue, as to maintain the skin elasticity.

The overall prognosis of CEVD is good, and most patients do not develop new lesions after the neonatal period. Nevertheless, the cosmetic impact of the permanent scarring should be addressed. $^{24}$

\section{Learning points}

- Congenital erosive and vesicular dermatosis (CEVD) is a rare dermatosis of the neonatal period that heals with a pathognomonic reticulate pattern.

- CEVD is strongly associated with prematurity.

- CEVD should be considered in the differential diagnosis of non-infectious erythematous plaques and erosions in neonates.
Acknowledgements We thank Dr Isabel Viana for her valuable contribution to the dermatopathology in this case.

Contributors AGP—study conception and planning; critical literature review; preparation and writing of the manuscript. LS-critical literature review and manuscript critical review. AL — critical literature review and manuscript critical review. CA - critical literature review and approval of the final version of the manuscript.

Funding The authors have not declared a specific grant for this research from any funding agency in the public, commercial or not-for-profit sectors.

Competing interests None declared.

Patient consent for publication Obtained.

Provenance and peer review Not commissioned; externally peer reviewed.

Case reports provide a valuable learning resource for the scientific community and can indicate areas of interest for future research. They should not be used in isolation to guide treatment choices or public health policy.

ORCID iD

Ana Lança http://orcid.org/0000-0001-5735-7332

\section{REFERENCES}

1 Tlougan BE, Paller AS, Schaffer JV, et al. Congenital erosive and vesicular dermatosis with reticulated supple scarring: unifying clinical features. J Am Acad Dermatol 2013:69:909-15.

2 Lee JH, Yoon SY, Lee JD, et al. A case of congenital erosive and vesicular dermatosis with limited involvement. J Am Acad Dermatol 2008;58:S104-6.

3 Wong V, Fischer G. Congenital erosive and vesicular dermatosis with reticulated supple scarring. Australas J Dermatol 2017;58:e236-9.

4 Polat $A$, Barbarot $S$, Bellanger $A$, et al. Congenital erosive and vesicular dermatosis healing with reticulated scarring. J Pediatr 2016;176:212-212.e1.

5 Hazarika N, Vathulya M, Joshi PP, et al. Congenital erosive and vesicular dermatosis in a young girl: a diagnostic dilemma. Int J Dermatol 2019;58:e212-4.

Copyright 2022 BMJ Publishing Group. All rights reserved. For permission to reuse any of this content visit

https://www.bmj.com/company/products-services/rights-and-licensing/permissions/

BMJ Case Report Fellows may re-use this article for personal use and teaching without any further permission.

Become a Fellow of BMJ Case Reports today and you can:

- Submit as many cases as you like

- Enjoy fast sympathetic peer review and rapid publication of accepted articles

- Access all the published articles

Re-use any of the published material for personal use and teaching without further permission

Customer Service

If you have any further queries about your subscription, please contact our customer services team on +44 (0) 2071111105 or via email at support@bmj.com.

Visit casereports.bmj.com for more articles like this and to become a Fellow 